monitoring of a single patient. Others have used changes in thoracic electrical impedance to measure pump performance non-invasively, but this has not given consistent results.

Our current methods of predicting perioperative cardiac risk are, then, characterised by uncertainty. Surgeons should take more responsibility for defining the risk in their own population of patients; if it is sufficiently high they should adopt a protocol for assessing individual patients. This will require selection for thallium scanning on the basis of clinical risk factors, with the possibility of coronary angiography for those found to have reversible defects on thallium imaging. Further studies are urgently needed to provide a reliable algorithm for non-invasive assessment of operative risk.

N MAMODE Registrar $S$ COBBE Professor

J G POLLOCK Consultant surgeon

Department of Peripheral Vascular Surgery and University Department of Cardiology, Glasgow Royal Infirmary,

Glasgow G31 2ER

1 Aitkenhead AR. Postoperative ischaemia: cardiac morbidity after non-cardiac surgery. Lancet 1987;341:731-2.
2 Gajraj $\mathrm{H}$, Jamieson $\mathrm{CW}$. Coronary artery disease in patients with peripheral vascular disease. $\mathrm{Br} \mathcal{f}$ Surg 1994;81:333-42.

3 Goldman L, Calder DL, Nussbaum SR, Southwick FS, Krogstad D, Murray B, et al. Multifactorial index of cardiac risk in noncardiac surgical procedures. $N$ Engl $f$ Med 1977;297:845-50.

4 Ashton CM, Petersen NJ, Wray NP, Kiefe CI, Dunn JK, Wu L, et al. The incidence of perioperative myocardial infarction in men undergoing noncardiac surgery. Ann Intern Med 1993;118:504-10.

5 Hertzer NK, Beven EG, Young JR, O'Hara PJ, Ruschhaupt WF, Graor RA, et al. A classification of 1000 coronary angiograms and results of surgical management. Ann Surg 1984;199:223-33.

6 Detsky AS, Abrams HB, Forbath N, Scott JG, Hilliard JR. Cardiac assessment for patients undergoing noncardiac surgery. Arch Intern Med 1986;146:2131-4.

7 Mangano DT. Perioperative cardiac morbidity. Anesthesiology 1990;72:153-84.

$8 \mathrm{McPhail}$ N, Calvin JE, Shariatmadar A, Barber GG, Scobie TK. The use of preoperative exercise testing to predict cardiac complications after arterial reconstruction. 8 Vasc Surg 1988;7:60-8.

9 Foster Ed, Davis KB, Carpenter JA, Abele S, Fray D. Risk of noncardiac operation in patients with defined coronary disease: the CASS registry experience. Ann Thorac Surg 1986;41:42-50.

10 Boucher CA, Brewster DC, Darling RC, Okada RD, Strauss HW, Pohost GM. Determination of cardiac risk by dipyridamole/thallium imaging before peripheral vascular surgery. $N$ Engl $₹$ Med 1985:312:389-94.

11 Eagle KA, Coley CM, Newell JB, Brewster DC, Darling RC, Strauss HW, et al. Combining clinical and thallium data optimizes preoperative assessment of cardiac risk before major vascular surgery. Ann Intern Med 1989;10:859-66.

12 Mangano DT, London MJ, Tubau JF, Browner WS, Hollenberg M, Krupski W, et al. Dipyridamole thallium-201 scintigraphy as a preoperative screening test; a reexamination of its predictive potential. Circulation 1991;84:493-502.

13 Baron JF, Mundler O, Bertrand M, Vicaut E, Barre E, Godet G, et al. Dipyridamole-thallium scintigraphy and gated radionuclide angiography to assess cardiac risk before abdominal aortic surgery. N Engl F Med 1994;330:663-9.

14 Lette J, Waters D, Cerino M, Picard M, Champagne P, Lapopinte J. Preoperative coronary artery disease risk stratification based on dipyridamole imaging and a simple 3-step, 3-segment model for patients undergoing noncardiac vascular surgery or major general surgery. Am $₹$ Cardiol 1992;69:1553-8.

15 McPhail NV, Ruddy TD, Barber GG, Cole CW, Marois J, Gulenchyn KY. Cardiac risk stratification using dipyridamole myocardial perfusion imaging and ambulatory ECG monitoring stratification using dipyridamole myocardial perfusion

16 Davila-Roman VG, Waggoner AD, Sicard GA, Geltman EM, Schechtman KB, Perez JE. Dobutamine stress echocardiography predicts surgical outcome in patients with an aortic aneurysm and peripheral vascular disease. $\mathcal{F} \mathrm{Am}$ Coll Cardiol 1993;21:957-63.

\title{
Antimony and health
}

\section{Incriminating stibine in the sudden infant death syndrome is difficult on current evidence}

Antimony is a metal in group $\mathrm{Vb}$ of the periodic system, just below arsenic, with which it shares several chemical and toxicological properties. Considered to be a non-essential trace element, it occurs naturally in the trivalent and pentavalent states with sulphur, mainly as stibnite ore $\left(\mathrm{Sb}_{2} \mathrm{~S}_{3}\right)$.

Antimony's main applications are industrial-it is used in alloys for hardening lead (for example, in batteries and bullets); in flame retardants for plastics; in semiconductors; and in therapeutics, in which it is applied in organic forms such as sodium stibogluconate in the treatment of leishmaniasis. Antimony potassium tartrate has been used as an emetic and as an intravenously administered anthelmintic. ${ }^{2}$ Relatively little is known of the toxicity of antimony compared with that of metals such as lead, cadmium, mercury, or arsenic. Recently, attention has been drawn to its possible role in the sudden infant death syndrome. ${ }^{34}$

The toxic effects of metals are related to the chemical form to which peoples are exposed. "Antimony toxicity" does not exist; every compound of the metal must be considered to be a separate toxicological entity. As with arsenic, ${ }^{5}$ the systemic toxicity of pentavalent compounds is considerably less than that of the trivalent compounds. The mechanism of toxicity of antimony compounds is unclear; it is probably related to the high affinity of the metal for sulphydryl (-SH) groups, which are essential for the structure and function of proteins. In a study of subacute toxicity in rats, sodium stibogluconate and meglumine antimoniate (which contain the pentavalent compound) given intramuscularly caused a fall in haemoglobin and blood glucose concentrations and an increase in liver enzymes and serum creatinine concentration. ${ }^{6}$ After long term inhalation of antimony trioxide by rats no effects on clinical chemical and haematological variables were observed. Corneal irregularities, which occurred after two weeks' exposure, and an increase in cataracts related to the dose were reported. Contrary to the findings of earlier studies, no increase in neoplasms was seen. ${ }^{7}$

The toxicity of stibine $\left(\mathrm{SbH}_{3}\right)$, a gas that forms when antimony is treated with acids, is analogous to but less fulminant than that of arsine $\left(\mathrm{AsH}_{3}\right)$. Haemolysis, myoglobinuria, haematuria, renal failure, nausea, vomiting, and headache have been reported in humans after inhalation. No recent experimental studies on the toxicity of stibine are available.

Unlike arsenic, inorganic trivalent antimony is not methylated in vivo but is excreted in the bile and urine after conjugation with glutathione. After short term intentional ingestion of stibnite by a 24 year old woman blood concentrations as high as $14.7 \mathrm{mmol} / 1$ (normal up to $2.9 \mathrm{mmol} / \mathrm{l}$ ) and urine concentrations of $1.8 \mu \mathrm{mol} / 1$ were observed without any clinical signs of intoxication. ${ }^{8}$ The initial excretion of antimony is rapid, but a slow component of excretion may exist as well. Deposition of inhaled antimonials may be retained in the lungs for years.'

Two populations are at risk of adverse effects of compounds of antimony: patients treated with antileishmaniasis agents and workers occupationally exposed to dusts and fumes containing antimony. ${ }^{9}$ The health effects described in both populations differ considerably owing to differences in exposure and the chemical form of the agents. Recently reported side effects of sodium stibogluconate are renal tubular acidosis, ${ }^{10}$ thrombocytopenia, ${ }^{11}$ and pancreatitis. ${ }^{12}$ A confounder in the determination of occupational health effects is that antimony ore contains arsenic as an impurity. The observed effects could therefore have been those of the contaminant rather than of antimony itself. ${ }^{9}$

Pneumoconiosis and other respiratory effects have been reported in workers. Cutaneous effects include a transient, generalised eruption of papules and pustules known as 
"antimony spots." Cardiovascular mortality and morbidity and electrocardiographic changes have been attributed to inhalation of the trisulphide. Acute inhalation of the volatile hydride stibine (for which an occupational exposure limit of $0.1 \mathrm{ppm}\left(0.5 \mathrm{mg} / \mathrm{m}^{3}\right)$ has been defined $\left.{ }^{13}\right)$ may lead to haemolytic anaemia and acute renal failure. Unlike trivalent arsenic, trivalent antimony has not been convincingly shown to be carcinogenic. ${ }^{9}$

Although the hypothesis that stibine formed by fungal transformation of fire retardants containing antimony in cot mattresses might be a cause of the sudden infant death syndrome is interesting, ${ }^{4}$ it receives insufficient toxicological support. Experiments do not substantiate the suggested anticholinesterase action for stibine. Using blood concentrations of antimony in the assessment of stibine poisoning is risky. The toxic effects of stibine differ considerably from those of the oxides, sulphides, or organic antimonials. In the assay of antimony in blood the total element is measured instead of the toxic entity. This means that antimony blood concentrations resulting from stibine exposure may never be compared with those resulting from other sources.

To evaluate the hypothesis, environmental and biological monitoring should go hand in hand. Sampling of the air inspired by babies on polyvinylchloride mattresses would give information on actual exposure, which could then be compared with occupational data on exposure to stibine. It is important to realise that the minute volume and the sensitivity to the toxic insult in infants may differ from those in adults; infants are usually exposed to ambient air considerably longer than an adult's 40 hour working week.

The sudden infant death syndrome long predates the invention of plastics containing antimony. A recent epidemio- logical study supports the scepticism towards the hypothesis of antimony trihydride being the cause of cot death. ${ }^{14}$ It is therefore most unlikely that, even after thorough toxicological evaluation, stibine will ever be convicted as the only cause of the syndrome.

Department of Human Toxicology,

FREDERIK A DE WOLFF

Academic Medical Centre,

University of Amsterdam,

Amsterdam,

Netherlands

1 Elinder C-G, Friber L. Antimony. In: Friberg L, Nordberg GF, Vouk VB, eds. Handbook on the toxicology of metals. 2nd ed. Vol II. Specific metals. Amsterdam: Elsevier, 1986:26-42.

2 Dieter MP. Toxicity studies of antimony potassium tartrate in F344/N rats and B6C3f mice. Research Triangle Park: US Department of Health and Human Services, 1992. (NIH publication No 92-3130.)

3 Flemming PJ, Cooke M, Chantlet SM, Golding J. Fire retardants, biocides, plasticisers, and sudden infant deaths. $B M \mp$ 1994;309:1594-6.

4 Richardson BA. Sudden infant death syndrome: a possible primary cause. $\mathcal{F}$ Forensic Sci Soc 1994:34:199-204.

5 De Wolff FA. Edelbroek PM. Neurotoxicity of arsenic and its compounds. In: de Wolff FA, ed. Vinken and Bruyn's handbook of clinical neurology. Part I. Intoxications of the nervous system. Amsterdam: Elsevier, 1994:283-91.

6 Alkhawajah A, Larbi EB, Jain S, Al-Gindan Y, Abahussain A. Subacute toxicity of pentavalent antimony compounds in rats. Hum Exp Toxicol 1992;11:283-8.

7 Newton PE, Bolte HF, Daly IW, Pillsbury BD, Terrill JB, Drew RT, et al. Subchronic and chronic inhalation toxicity of antimony trioxide in the rat. Fundam Appl Toxicol 1994;22:561-76.

8 Bailly R, Lauwerys R, Buchet JP, Mahieu P, Konings J. Experimental and human studies on Bailly $R$, Lauwerys $R$, Buchet $J P$, Mahieu $P$, Konings $J$. Experimental and human studies on
intimony metabolism: their relevance for the biological monitoring of workers exposed to

9 Apostoli P, Porru S, Alessio L. Antimony. Biological indicators for the assessment of human exposure to industrial chemicals. Luxembourg: European Commission, 1994:1-21. (Report EUR 14815 EN.)

10 Horber FF, Lerut J, Jaeger P. Renal tubular acidosis, a side effect of treatment with pentavalent antimony. Clin Nephrol 1991;36:213.

11 Braconier JH, Miorner $\mathrm{H}$. Recurrent episodes of thrombocytopenia during treatment with sodium stibogluconate. F Antimicrob Chemother 1993;31:187-8.

12 Gasser RA, Magill AJ, Oster CN, Franke ED, Grogel M, Berman JD. Pancreatitis induced by pentavalent antimonial agents during treatment of leishmaniasis. Clin infect Dis 1994;18:83-90.

13 Kentner M, Leinemann M. Umwelt- und arbeitsmedizinische Bedeuting von Antimon und seinen wichtigsten Verbindungen. Zentralblatt für Arbeitsmedizin 1994;44:46-55.

14 Blair P, Fleming P, Bensley D, Smith I, Bacon C, Taylor E. Plastic mattresses and sudden infant death syndrome. Lancet 1995;345:720.

\section{Use of chloramphenicol as topical eye medication: time to cry halt?}

\section{Bone marrow aplasia also occurs with ocular use}

Chloramphenicol accounts for over half the general medical services prescriptions for ocular antibiotics in the Republic of Ireland, while in the United Kingdom 55\% of patients presenting to general practitioners with "red eyes" are treated with chloramphenicol eye ointment. ${ }^{1}$ The British National Formulary currently recommends chloramphenicol as the drug of choice for superficial eye infections. It has the advantage that it has a broad spectrum of activity and rarely causes local irritation or hypersensitivity, which may be a problem with other antibiotics. Yet on our wards we no longer prescribe topical ocular chloramphenicol. Why?

Since 1950, when Rich et al highlighted the relation between oral chloramphenicol and bone marrow aplasia, ${ }^{2}$ doctors have been well aware of this side effect. The first death resulting from bone marrow aplasia induced by chloramphenicol eye drops was described by Rosenthal and Blackman in $1955 .^{3}$ Numerous subsequent articles directly implicated chloramphenicol eye drops in causing bone marrow aplasia, ${ }^{4-7}$ and after the publication of Fraunfelder et al's paper ${ }^{6}$ in 1982 the sale of chloramphenicol eye drops in the United States fell by $80 \%$ in two years. ${ }^{8}$ By 1993 the national register of drug induced ocular side effects (in Oregon) had received reports of 23 patients with blood dyscrasias that might have been related to topical ocular administration of chloramphenicol. ${ }^{8}$

This caution over the association is important since there are several problems in directly implicating ocular chloramphenicol as a cause of blood dyscrasias. Firstly, clinicians do not usually ask about eye drops or ointment when taking a drug history; secondly, many patients do not realise that they have used ocular chloramphenicol; thirdly, blood dyscrasias may develop weeks to months after treatment has been stopped"; and, finally, some of the reactions are idiosyncratic. All these difficulties underline the importance of an extensive drug history.

Oral chloramphenicol causes two types of bone marrow toxicity. ${ }^{\circ}$ The first is a dose related reversible depression generally affecting erythroid cells, which is thought to be mediated by mitochondrial injury; the second is an idiosyncratic reaction, which affects all three cell lines and is generally fatal. In the second type a nitroreduction derivative of chloramphenicol produced by a predisposed patient is thought to induce damage to DNA in stem cells, leading to blood dyscrasias. The ultimate toxic derivative of chloramphenicol may be produced in the marrow in situ, thus making the marrow both the site of metabolic conversion and the target of injury. Genotoxicity in stem cells may make them non-proliferative or, alternatively, may initiate marrow damage mediated by the immune system. The occurrence of aplastic anaemia with the small doses characteristic of topical chloramphenicol is thus consistent with the hypothesis of an individual metabolic predisposition. ${ }^{8}$ Ocular chloramphenicol may therefore cause this idiosyncratic reaction only in genetically predisposed people, and a personal or 